\title{
An interdisciplinary assessment of climate engineering strategies
}

\author{
Daniela F Cusack $^{1 *}$, Jonn Axsen ${ }^{2}$, Rachael Shwom ${ }^{3}$, Lauren Hartzell-Nichols ${ }^{4}$, Sam White ${ }^{5}$, \\ and Katherine RM Mackey ${ }^{6,7}$
}

Mitigating further anthropogenic changes to the global climate will require reducing greenhouse-gas emissions ("abatement"), or else removing carbon dioxide from the atmosphere and/or diminishing solar input ("climate engineering"). Here, we develop and apply criteria to measure technical, economic, ecological, institutional, and ethical dimensions of, and public acceptance for, climate engineering strategies; provide a relative rating for each dimension; and offer a new interdisciplinary framework for comparing abatement and climate engineering options. While abatement remains the most desirable policy, certain climate engineering strategies, including forest and soil management for carbon sequestration, merit broad-scale application. Other proposed strategies, such as biochar production and geological carbon capture and storage, are rated somewhat lower, but deserve further research and development. Iron fertilization of the oceans and solar radiation management, although cost-effective, received the lowest ratings on most criteria. We conclude that although abatement should remain the central climate-change response, some low-risk, cost-effective climate engineering approaches should be applied as complements. The framework presented here aims to guide and prioritize further research and analysis, leading to improvements in climate engineering strategies.

Front Ecol Environ 2014; 12(5): 280-287, doi:10.1890/130030

$\mathrm{C}$ urrent climate policies call for reducing greenhousegas (GHG) emissions to avoid a projected doubling of atmospheric carbon dioxide $\left(\mathrm{CO}_{2}\right)$ by 2100 (IPCC 2007). Competing proposals aim to reduce atmospheric $\mathrm{CO}_{2}$ or promote Earth-surface cooling in other ways. We term the latter as "climate engineering" options, because they are direct, large-scale actions for altering temperature. Climate engineering could be useful for averting rapid, catastrophic climate change, and might prove more cost-effective than rapid "abatement" (defined here

\section{In a nutshell:}

- Abatement of greenhouse-gas emissions should remain the focus of climate-change policy

- Given their associated uncertainties and risks, climate engineering strategies best serve as complements to abatement

- We provide a framework to assess climate engineering strategies and demonstrate the importance of considering criteria such as cost effectiveness, ecological risk, and institutional capacity

- These strategies are evaluated and ranked according to each criterion within the framework, based on relative risks

- Forest and soil management for carbon storage received the highest ratings across criteria

- Options such as biochar production, which localize risk and can be implemented by individual entities, hold greater promise than options like solar radiation management, which may have widespread unintended consequences

${ }^{1}$ Department of Geography, University of Califormia, Los Angeles, Los Angeles, CA *(dcusack@geog.ucla.edu); ${ }^{2}$ School of Resource and Environmental Management, Simon Fraser University, Burnaby, Canada; ${ }^{3}$ Department of Human Ecology, Rutgers University, New Brunswick, NJ (continued on p287) as the reduction in GHG emissions through efficiency, conservation, or transitioning to low-carbon [C] fuels). Increased concern about the pace of abatement and projected effects of climate change has drawn attention to climate engineering, as reflected in the IPCC AR5 (IPCC 2013). Past assessments have compared engineering options (Keith 2000; Shepherd et al. 2009; ASOC 2010; GAO 2011; Vaughan and Lenton 2011), but prioritization and implementation of strategies require a more comprehensive appraisal that encompasses human and environmental consequences in addition to technical and economic feasibility.

We propose a unique interdisciplinary framework for comparing climate engineering strategies using six criteria: (1) technical potential, (2) cost effectiveness, (3) ecological risk, (4) public acceptance, (5) institutional capacity, and (6) scope of ethical concerns (Figure 1). By analyzing the leading climate engineering proposals according to these criteria (Figure 2; Table 1), with abatement (as opposed to no action taken; WebTable 1) as a basis for comparison, this framework includes a broader array of criteria than that of previous assessments, and each criterion is addressed in terms of the best available literature. This multi-attribute trade-off approach does not apply weights to the criteria, but instead employs a collaborative approach to produce numerical scores for each criterion and strategy (WebTables 1-3). Here, we (1) focus on preferable strategies to mitigate anthropogenic climate change; (2) provide a coherent interdisciplinary discussion to assist international-level decision makers in selecting strategies best suited to their institutional strengths, and valuating risks and benefits; and (3) encourage analysts to 
propose alterations to the assessment methodology, to conduct further research, and ultimately to improve management and implementation of climate engineering.

In our assessment, some strategies pose substantial multi-dimensional challenges, whereas others offer feasible complements to abatement. We briefly introduce the strategies, and then apply the six criteria.

\section{Strategies}

This section describes abatement and climate engineering strategies, focusing on the maximum potential effect (ie $\mathrm{C}$ sequestration or cooling effects) of each. Underdeveloped strategies (eg accelerated weathering of rock) are described but not analyzed further.

\section{Abatement}

Carbon abatement reduces GHG emissions through means such as energy efficiency, conservation, and fuel switching. To illustrate, Pacala and Socolow (2004) identified several $\mathrm{CO}_{2}$ reduction methods equivalent to offsetting 1 gigaton of $\mathrm{C}$ per year (GT C $\mathrm{yr}^{-1}$ ), including doubling vehicle fuel economy (efficiency), reducing vehicle use by one-half (conservation), or switching vehicle fuels from petroleum to biomass (fuel switching). Consensus estimates suggest that abatement could theoretically reduce GHG emissions by 7 GT C yr ${ }^{-1}$ by 2030 (IEA 2011). To put this into perspective, human activity adds $\sim 9$ GT $\mathrm{C} \mathrm{yr}^{-1}$ to the 800 GT already present in the atmosphere (IPCC 2007). Forest regrowth and dissolution of $\mathrm{CO}_{2}$ into oceans remove $\sim 5 \mathrm{GT} \mathrm{C} \mathrm{yr}^{-1}$ from the atmosphere, but this uptake is projected to diminish over time, leaving at least $4 \mathrm{GT} \mathrm{C} \mathrm{yr}^{-1}$ to abate, sequester, or cancel out (Cox et al. 2000).

\section{Biological $C$ sequestration}

These strategies are based on the photosynthetic activity of living organisms and on storage of organic $\mathrm{C}$ in plants and soils. Several approaches have received considerable attention. First, reducing deforestation and promoting forest growth globally could sequester an estimated 1.3 GT $\mathrm{C} \mathrm{yr}^{-1}$ in biomass, with deforestation currently contributing $>1 \mathrm{GT} \mathrm{C} \mathrm{yr}^{-1}$ to the atmosphere (Mackey et al. 2013). Second, because agriculture has led to the loss of about one-half (55-78 GT) of stored soil C from tilled lands, improved agricultural and plantation management could restore an estimated 0.4-1.1 GT C yr ${ }^{-1}$ (Lal 2001). Third, biochar production uses high-temperature combustion with minimal $\mathrm{CO}_{2}$ release to convert plant tissue into condensed $\mathrm{C}$ that can persist in soils for millennia
(Lehmann et al. 2006). Approximately $0.65 \mathrm{GT} \mathrm{C} \mathrm{yr}^{-1}$ could be sequestered with amendments of biochar to agricultural soils worldwide (Sohi et al. 2009). Fourth, marine algae are responsible for one-half of global $\mathrm{CO}_{2}$ conversion into biomass; fertilizing the ocean with scarce elements such as iron can promote growth of algal blooms and subsequent deep-sea sequestration of biomass, potentially storing 0.7-2.3 GT C yr ${ }^{-1}$ (Aumont and Bopp 2006).

\section{Abiotic C sequestration}

Strategies include carbon capture and storage (CCS) from point sources and diffuse sources, and accelerated weathering of rock. Point-source CCS scrubs $\mathrm{CO}_{2}$ emitted from industrial coal and natural gas combustion, then concentrates and pumps it into geological formations on land or in the ocean. Abiotic CCS currently stores on the order of megatons of $\mathrm{C}$ per year globally, but has the potential to remove $>1 \mathrm{GT} \mathrm{C} \mathrm{yr}^{-1}$, or up to $545 \mathrm{GT} \mathrm{C}$ total over time (IPCC 2007; Herzog 2011). Capture of C from ambient air (ie a diffuse source) would separate $\mathrm{CO}_{2}$ from atmospheric gases, but is currently impractical because of energy and cost requirements (an estimated $\$ 1000$ per ton; all dollar amounts here and throughout are in US\$; House et al. 2011). Accelerated weathering would convert $\mathrm{CO}_{2}$ into stable carbonates through chemical reaction with metal 


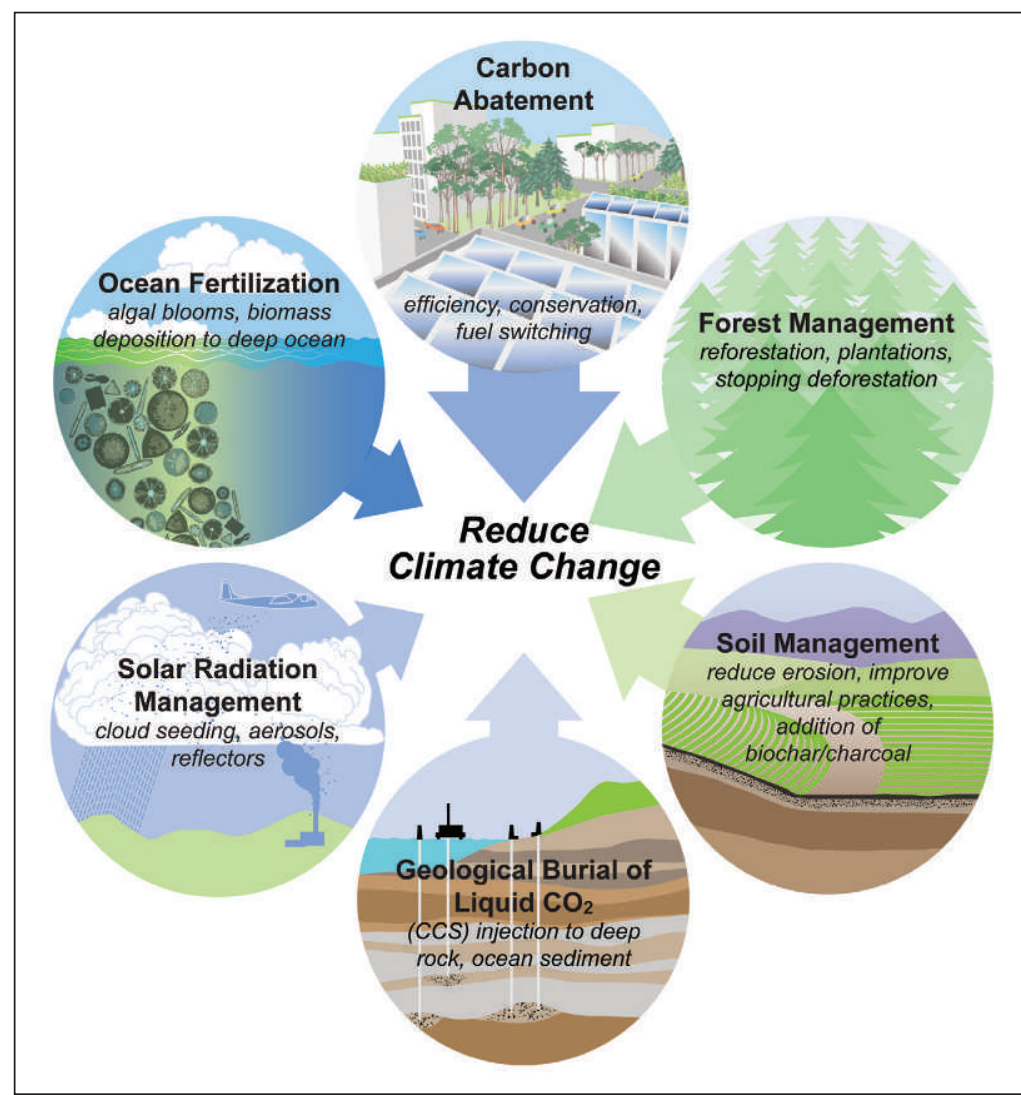

Figure 2. The climate engineering strategies assessed here are illustrated, with different sized arrows showing the relative rating of different strategies at reducing climate change. Examples and descriptions of each strategy are given. droplet concentration, outer-atmosphere reflectors, and whitening of surfaces in cities, oceans, and deserts (GAO 2011). The projected cooling potential of combined SRM strategies is slightly higher than the predicted effects of forest-management $\mathrm{C}$ sequestration (WebTable 1).

\section{Application of criteria}

\section{Technical potential}

Technical potential here refers to the technological feasibility of implementing a strategy, the potential for increasing total $\mathrm{C}$ storage, and the duration of $\mathrm{C}$ storage.

The technical potential for abatement is extremely high, because efficiency, conservation, and fuel switching have all been tested and developed much more extensively than climate engineering strategies. To be effective, abatement efforts must be sustained in perpetuity.

Forest management and regrowth present few technological obstacles. However, availability of suitable land constrains implementation, and plant or plantation life spans limit the duration of aboveground C storage. Less is known about how to implement soil management for large-scale, long-term C storage, oxides, but energy requirements make this unfeasible with current technologies (Anderson and Newell 2004). Thus, subsequent sections analyze only point-source CCS.

\section{Solar radiation management (SRM)}

These efforts aim to reduce solar energetic input to Earth, where it turns into radiant heat, by increasing albedo (reflectance). Proposed methods include stratospheric aerosols, marine cloud brightening via increased water which depends on highly uncertain effects of ecosystem properties, land-use history, and organic tissue chemistry (Schmidt et al. 2011). For biochar, although efficient combustion technology is available, resistance to decomposition over the long term is likely to vary across sites, depending on properties such as microbial activity and soil mineralogy (Cusack et al. 2013; Gurwick et al. 2013). Widespread application of biochar to soils, as well as availability of biomass inputs for production, present technical challenges. Although ocean fertilization

\section{Table 1. Interdisciplinary framework to assess climate engineering strategies}

\begin{tabular}{|c|c|c|c|c|c|c|}
\hline & Technical potential & Cost effectiveness & Ecological risk & $\frac{\text { Instia }}{\text { Instutional capacity }}$ & Public acceptance & Scope of ethical concerns \\
\hline \multirow{6}{*}{ 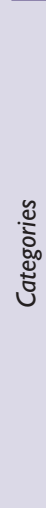 } & $\begin{array}{l}\text { (a) Carbon } \\
\text { sequestration } \\
\text { potential }\end{array}$ & $\begin{array}{l}\text { (a) Cost per ton } \\
\mathrm{CO}_{2} \text { reduction } \\
\text { equivalent }\end{array}$ & $\begin{array}{l}\text { (a) Physical and } \\
\text { chemical side effects } \\
\text { on ecosystems }\end{array}$ & $\begin{array}{l}\text { (a) Locus of decision } \\
\text { making }\end{array}$ & $\begin{array}{l}\text { (a) Perceived risks } \\
\text { and costs }\end{array}$ & (a) Governance \\
\hline & $\begin{array}{l}\text { (b) Global cooling } \\
\text { potential }\end{array}$ & (b) Cost uncertainty & $\begin{array}{l}\text { (b) Biological effects } \\
\text { on organisms }\end{array}$ & $\begin{array}{l}\text { (b) Distribution of } \\
\text { benefits/risks }\end{array}$ & (b) Trust & $\begin{array}{l}\text { (b) Responsibility for } \\
\text { consequences }\end{array}$ \\
\hline & \multirow[t]{4}{*}{$\begin{array}{l}\text { (c) Likely duration of } \\
\text { sequestration } \\
\text { effectiveness (years) }\end{array}$} & & $\begin{array}{l}\text { (c) Potential } \\
\text { feedbacks to } \\
\text { warming }\end{array}$ & (c) Time scale & (c) Fairness & (c) Burdens of action \\
\hline & & & $\begin{array}{l}\text { (d) Life-cycle } \\
\text { assessment (energy } \\
\text { required to initiate) }\end{array}$ & $\begin{array}{l}\text { (d) Observability of } \\
\text { option }\end{array}$ & $\begin{array}{l}\text { (d) Perceived } \\
\text { "naturalness" }\end{array}$ & (d) Acceptability of risk \\
\hline & & & & & & (e) Weighing options \\
\hline & & & & & & (f) Moral failure to abate \\
\hline
\end{tabular}


appears to be technically simple, requiring only distribution of minerals (de Baar et al. 2005), its effectiveness depends on algal cells sinking into the deep ocean. Field studies have found that only a small percentage of the $\mathrm{C}$ from fertilized algal blooms $(<25 \%)$ sinks to the deep ocean (de Baar et al. 2005), a smaller fraction than that from natural blooms (Landry et al. 2000).

Point-source CCS is well developed and has been used successfully for several decades to improve oil recovery. However, the possibility of leakage of $\mathrm{CO}_{2}$ from storage could seriously compromise the strategy's long-term potential. Achieving the same long-term climate benefits as low-emission abatement scenarios would require leakage rates from storage sites less than $1 \%$ per thousand years (Shaffer 2010). While some offshore marine locations may carry lower risks of leakage, monitoring these remote sites poses an additional technical hurdle.

All SRM strategies would require not only further research and development before implementation (GAO 2011), but also continual maintenance for long-term effectiveness. Space-based reflectors present extreme management challenges. Ground-whitening solutions are limited by the relatively small area that could be lightened. Marine cloud brightening presents technological challenges for continual suspension of water droplets. This leaves stratospheric aerosols as the most technically viable option, although questions about appropriate particle size and duration remain; subsequent discussion of SRM focuses on this strategy.

\section{Cost effectiveness}

The cost effectiveness of climate engineering strategies is framed here as marginal costs, or dollars spent to reduce $\mathrm{CO}_{2}$ emissions (or the equivalent in terms of avoided climate warming) by one incremental ton.

For abatement, the costs range from $\$ 20-200$ per ton of $\mathrm{CO}_{2}$ (IPCC 2007; Stern 2007) but vary widely by technology, sector, region, timescale, and magnitude. Faster, deeper cuts impose higher marginal costs. For example, one US estimate for abatement is $\$ 10$ per ton for a $10 \%$ reduction in $\mathrm{CO}_{2}$, but over $\$ 120$ per ton for a $50 \%$ reduction (Morris et al. 2012).

Climate engineering proposals often promise low costs relative to abatement (Barret 2008). Nevertheless, estimates are subject to considerable uncertainty and are often presented as a single cost, ignoring marginal costs. Regarding biological sequestration, forest management and ocean fertilization are considered the most cost-effective approaches, followed by soil management and biochar strategies (Shepherd et al. 2009; Rickels et al. 2012). However, preliminary estimates may be overly optimistic. Ocean fertilization, for instance, was initially proposed at only $\$ 2$ per ton $\mathrm{CO}_{2}$, but more recent analysis suggests costs from $\$ 8-80$ per ton (Boyd 2008).

For geological CCS, costs vary dramatically by industry, ranging from $\$ 15$ per ton in natural gas processing to
$\$ 130$ per ton in the cement sector (IEA GHG 2008). Much less is known about the costs of ocean-based CCS due to a lack of experience with this technique.

SRM is often portrayed as the cheapest strategy, potentially costing only a few dollars per ton $\mathrm{CO}_{2}$ equivalent for some strategies (Shepherd et al. 2009). Yet to sustain lower temperatures, SRM would require perpetual maintenance that would most likely lead to higher costs and increased management challenges. Given the risk of sudden warming if the strategy were abandoned, these costs would be incurred indefinitely.

\section{Ecological risk}

Ecological risk is the potential for loss of ecosystem function, biodiversity, and/or organism interactions, and overall threat to the integrity of the global biosphere.

Abatement poses little ecological risk, although there are potential risks from some energy-saving materials (eg mercury in compact fluorescent bulbs), and the effects of land-use changes associated with alternative fuels (Costanza 1980).

Forest and soil management appear to be ecologically attractive options because they are linked to ecosystem restoration, but there are geographical concerns. For example, increasing forest cover in snow-covered, high-latitude regions could contribute to warming by darkening the Earth's surface. However, this effect could be offset by changes in surface reflectance elsewhere. Another concern is that reforestation or plantations on degraded lands may require fertilization and/or irrigation, potentially producing additional GHGs via off-gassing, and reducing regional water availability. Establishing forests in previously unforested areas might also alter weather patterns due to surface roughness and transpiration of water to the atmosphere from trees (Bala et al. 2007). Soil management on agricultural lands appears to carry minimal risks (Schmidt et al. 2011) but may affect nutrient and water retention (Glaser et al. 2001). Biochar requires substantial inputs of biomass, which could pose a risk to natural ecosystems. Still, most proposals for widespread biochar production promote use of biomass from "weedy" grasses grown on marginal, unforested lands that are unsuitable for agriculture (eg degraded lands), or use of timber byproducts. The ecological effects of widespread biochar amendment to non-agricultural soils remain poorly understood.

Ocean fertilization carries more serious ecological risks. Algal biomass can be consumed by bacteria, creating anoxic conditions that may make areas uninhabitable for marine animals. Iron fertilization can also favor the growth of opportunistic algae, changing the structure of the marine food web and potentially producing toxins (Silver et al. 2010), including emissions of dimethyl sulfide gas that promote cloud formation and may alter climate patterns (Wingenter et al. 2004). These and other ecological consequences are difficult to contain and monitor because ocean circulation would spread the fertilizer over extensive areas. 
CCS methods are associated with the risk of accidental leakage of concentrated liquid $\mathrm{CO}_{2}$, which displaces oxygen and can lead to human suffocation if the gas reaches high concentrations in nearby areas (Kling et al. 1987). Injection of $\mathrm{CO}_{2}$ underground also has the potential to cause small earthquakes (Zoback and Gorelick 2012). Storage of $\mathrm{CO}_{2}$ in the deep ocean could lead to extreme ocean acidification and high levels of dissolved $\mathrm{CO}_{2}$ in the water column (Shaffer 2010), affecting marine animals and microbial communities.

SRM carries ecological risks of uncertain but potentially serious magnitude and duration. The risks associated with intervening in global atmospheric systems are extremely high, since a single intervention can cause multiple nonlinear feedbacks to weather and climate patterns over multiple timescales (Hansen et al. 2007). Furthermore, by focusing solely on temperature, SRM fails to address other issues associated with rising $\mathrm{CO}_{2}$ in the atmosphere, such as ocean acidification.

\section{Institutional capacity}

The term institution here refers to a system of rights, rules, and decision-making procedures for a climate engineering option (Young et al. 2008). Institutional capacity is the ability of these systems to effectively govern a climate engineering approach. Five primary characteristics of any given engineering strategy influence the capacity to govern it: (1) the number of decision makers needed for implementation; (2) distribution of risks and benefits, which determines stakeholders and influences consensus-building; (3) uncertainty regarding the possible harms and benefits of an engineering strategy, which inform how adaptive an institution must be; (4) how permanent or impermanent a climate engineering strategy is once in place, which can require durable institutions and institutional memory; and (5) the option's ability to be seen or measured, which influences ease of monitoring and enforcement (Dietz et al. 2007). Prominent discussions of institutional rules have focused on managing research and results, using informed consent, and creating institutional review boards (Kintisch 2010).

One of the biggest challenges for climate engineering is that each strategy varies greatly in the characteristics described above; therefore the optimal decision-making procedures, rules, and rights also vary greatly. The range in scale, in the nature of risks and uncertainties, and in the ease or difficulty of enforcement suggests that a polycentric system (ie having many centers of governance) with a loose coordinating structure might be the best approach. Components of the plan must be managed and enforced by specific countries, which have varying degrees of capacity for monitoring and enforcement, around the globe.

Abatement could be achieved through a variety of policy mechanisms, including $\mathrm{C}$ pricing, cap-and-trade, technology standards, and incentive programs; organizations could verify decreased energy use through energy monitoring systems. However, fragmentation of relevant markets and a diversity of decision-making processes pose major challenges to the implementation of abatement measures (Wilson et al. 2012). For instance, there is the problem of split incentives, where those who invest in efficient technologies (eg multifamily building owners) do not always benefit from the savings (eg lower energy bills for tenants). Market policies may address some of these challenges. Energy efficiency policies have historically been implemented at local and national levels; emerging efforts such as the Super-efficient Equipment and Appliance Deployment Initiative use global energy efficiency standards, labeling, and procurement to coordinate action between non-governmental organizations and industrialized and developing nations to coordinate a "global market transformation".

Regarding biotic sequestration options, forest and soil management appear considerably easier to govern than the other engineering strategies. They can be undertaken nationally and managed at local levels, pose low risk of harm, yield benefits in the aggregate, and are easier to enforce. Forest and soil management, however, would require long-term monitoring and international cooperation to be effective on a global scale.

Ocean fertilization presents greater challenges because it would have to take place in international waters, the stakeholders are less obvious, the risks of harmful ecological impacts are high, and there is great uncertainty regarding $\mathrm{C}$ sequestration benefits. Corporations tested this strategy in the absence of regulation until 2008, when the UN Convention on Biological Diversity placed a moratorium on large-scale commercial ocean fertilization (Tollefson 2008). Recent rogue ocean fertilization events have placed the effectiveness of this moratorium in question (Fountain 2012) and highlight the need for international cooperation.

Abiotic C storage options present complex institutional challenges, in particular the need for long-term monitoring to prevent $\mathrm{CO}_{2}$ leakage into the atmosphere from underground reservoirs. CCS can be undertaken at the local level by a small number of decision makers and is currently regulated in the US at the federal level by the Environmental Protection Agency. It is associated with moderate and uncertain risks of ecological damage that would be relatively localized, so governing institutions should engage local stakeholders.

SRM is extremely challenging to govern. It poses potentially large-scale risks to the climate system, yet could be put into action by only a few decision makers. Risks and benefits are distributed differentially worldwide, depending on changes in weather patterns. SRM governance would entail consistent monitoring to integrate new information and maintain agreed-upon targets, and would require restraining and coordinating actions.

\section{Public acceptance}

The public acceptance criterion assesses whether citizens will embrace, tolerate, or resist a given strategy. Relevant factors include: (1) perceptions of favorable 
benefits; (2) costs and risks; (3) knowledge and trust of the technology; (4) trust in the actors implementing the strategy; (5) fairness in decision making; and (6) equitable distribution of cost and benefits (Huijts et al. 2012). Because public awareness of climate engineering strategies is minimal (Sharp et al. 2009; GAO 2011; Mercer et al. 2011), it is difficult to assess public opinion, and thus estimates of public acceptance remain preliminary (Malone et al. 2010). Current research relies on surveys, qualitative interviews, and focus groups wherein researchers first explain a strategy and then elicit opinions from participants. This approach may provide a baseline for acceptance, but public perceptions can change with exposure to different types of information (Stephens et al. 2009) and public consultation (Terwel et al. 2010).

When discussing abatement, members of the public are likely to be more supportive of subsidies for efficient technologies, less supportive of technology-forcing standards (ie requirement to achieve an emissions limit), and least supportive of taxes on C or fuels (Dietz et al. 2007). Thus, support tends to be lowest for the abatement policies that are most likely to be effective (eg C pricing). Policy makers' perceptions of such public resistance tend to prevent enactment of stringent abatement policies (Harrison 2012).

A survey of $>1000$ US citizens found that the majority supported research on climate engineering once it was explained, although support for abatement was higher (GAO 2011). Public support appears to be highest for approaches perceived as more "natural", such as restoring an ecosystem as opposed to developing a new technology (NERC 2010). Support would likely be highest for techniques involving land-based biomass, including forest and soil management and biochar burial, as the public often associate these strategies with returning the Earth to a "natural" state, with little potential for environmental risk or negative social impacts. Ocean fertilization tends to be viewed with suspicion and is strongly associated with negative impacts and high environmental risk (NERC 2010).

Among abiotic strategies, geological CCS has the potential to receive public support. One survey of $>1000$ Canadians found that once the potential benefits and risks of geological CCS were explained, respondents perceived CCS to be considerably less risky than existing oil and gas operations, coal-powered plants, and nuclear power, but more risky than wind turbines (Sharp et al. 2009). Acceptance of deep-sea CCS depended on the respondents' perceptions of affected locations (Kamishiro and Sato 2009) and might face more resistance given the potential for negative marine ecological effects and international water disputes.

When SRM was explained to citizens in the US, UK, and Canada, there was general support for further research, but also some suspicion and distrust relating to the technology and its governance (NERC 2010; Mercer et al. 2011).

\section{Scope of ethical concerns}

Climate change presents a moral dilemma involving issues of justice, the value of nonhuman nature, and obligations to future generations (Gardiner 2011). Similarly, climate engineering poses complex moral questions (Preston 2012). Key ethical concerns include: (1) who should govern; (2) burden-sharing and distribution of costs; (3) levels of acceptable risk; (4) weighing options against alternatives; (5) responsibility for harmful consequences; and (6) background moral failure given the lack of effective abatement efforts to date. Climate engineering policies and research that fail to address these issues pose further ethical risks (Tuana et al. 2010). In general, climate interventions should have predictable consequences and should not violate well-founded ethical principles (Jamieson 1996). They must be shown to be safe before implementation (Shepherd et al. 2009), although standards of proof and safety remain a matter for debate (Hartzell-Nichols 2012). Abatement also raises some ethical concerns associated with the distribution of social costs, but these are relatively minor as compared to those associated with climate engineering approaches.

Among climate engineering strategies, forest and soil management have the lowest risk of unintended consequences, which minimizes the above-described concerns. This approach therefore generates the least ethical concern, followed by biochar and geological CCS. Ocean fertilization and deep-sea CCS entail substantial risks of unintended consequences, including ecological effects and $\mathrm{CO}_{2}$ leakage. SRM presents a particularly extreme ethical case. To be ethical, such a scale of climate engineering may require worldwide consent (Preston 2012). Also, climate engineering strategies undertaken to replace rather than complement abatement pose far greater concerns (Schneider 1996), as do measures more likely to generate irreversible changes and major harmful consequences (Corner and Pidgeon 2010), as SRM might.

\section{Conclusions}

The climate engineering strategies assessed here raise complex questions and considerable uncertainties. Nevertheless, this review points to some meaningful conclusions. In light of their limitations and risks, climate engineering approaches would best serve as a complement to - rather than replacement for - abatement, and the latter should remain a focus of climate-change policy for the foreseeable future.

Climate engineering efforts should focus first on lowrisk strategies, including measures with more reliable and well-tried technologies, moderate costs, low ecological risks, ease of governance, wide public acceptance, and few moral concerns. The framework applied here gives the most positive ratings to forest and soil management for C storage - more than other strategies such as biochar and geological CCS (Figure 3). Yet biochar application to 


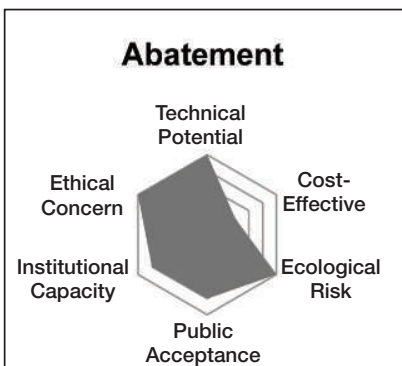

Ocean Iron Fertilization

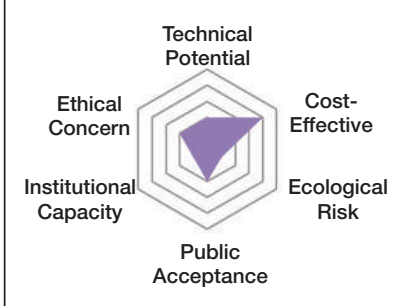

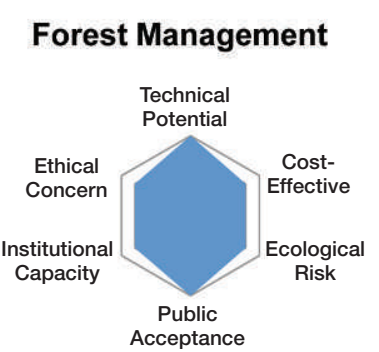

Geological CCS

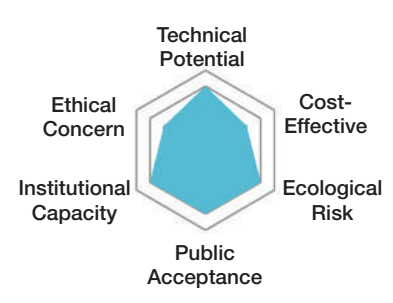

Soil Management

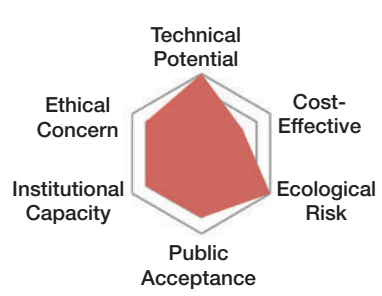

Ocean CCS

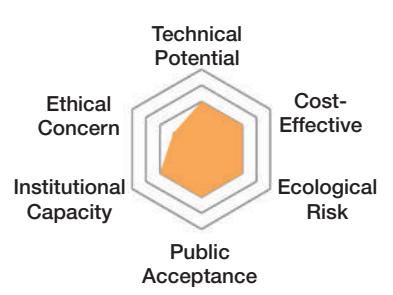

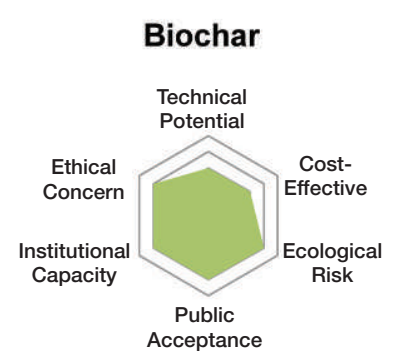

Stratospheric Aerosols

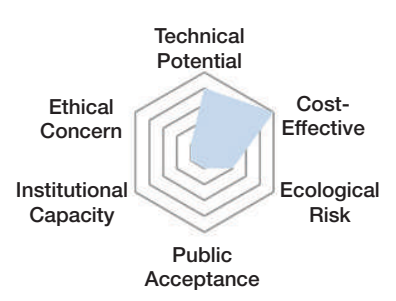

Figure 3. Results from the interdisciplinary analysis of abatement and climate engineering strategies are shown. All six criteria are scaled on radar charts so that a higher value is more likely to be an effective strategy, with abatement and forest and soil management receiving the highest all-around scores. Details on how scores were assessed are available in WebTables 1-3.

soils and geological CCS could be managed nationally or regionally as part of a global plan, and these options merit further research and development. Low-cost, high-impact options including ocean fertilization and SRM present more serious drawbacks in terms of ecological risk, institutional capacity, and ethical concerns.

Historically, climate engineering proposals have had a poor track record in terms of feasibility, governance, and risks (Fleming 2010). However, technologies, costs, institutions, and public perceptions associated with all strategies - including abatement - are continually changing. As with many past environmental problems, there might be a largely engineered solution for climate change. Yet historical experience suggests an answer would more likely emerge from an evolution of technologies, institutions, and public behaviors than from a single technical fix (Tarr 1996).

\section{Acknowledgements}

We thank the NSF funded Dissertations Initiative for the Advancement of Climate Change Research symposium of 2011 for providing the format to initiate this work, and the organizers S Weiler and R Mitchell. Illustrations are by M Zebrowski, cartographer, UCLA. NSF grant \#1103575 supported KRMM.

\section{References}

Anderson S and Newell R. 2004. Prospects for carbon capture and storage technologies. Annu Rev Env Resour 29: 109-42.

ASOC (Asilomar Scientific Organizing Committee). 2010. The Asilomar Conference recommendations on principles for research into climate engineering techniques. Washington, DC: Climate Institute.

Aumont $\mathrm{O}$ and Bopp L. 2006. Globalizing results from ocean in situ iron fertilization studies. Global Biogeochem Cy 20: GB2017.

Bala G, Caldeira K, Wickett M, et al. 2007. Combined climate and carbon-cycle effects of large-scale deforestation. P Natl Acad Sci USA 104: 6550-55.

Barret S. 2008. The incredible economics of geoengineering. Environ Resour Econ 39: 45-54.

Boyd P. 2008. Implications of large-scale iron fertilization of the oceans. Mar Ecol-Prog Ser 364: 213-18.

Corner A and Pidgeon N. 2010. Geoengineering the climate: the social and ethical implications. Environ Sci Policy Sust Dev 52: 24-37.

Costanza R. 1980. Embodied energy and economic valuation. Science 210: 1219-24.

Cox PM, Betts RA, Jones CD, et al. 2000. Acceleration of global warming due to carbon-cycle feedbacks in a coupled climate model. Nature 408: 184-87.

Cusack DF, Chadwick OA, Hockaday WC, and Vitousek PM. 2013. Mineralogical controls on soil black carbon preservation. Global Biogeochem Cy 26: GB2019.

de Baar HJW, Boyd PW, Coale KH, et al. 2005. Synthesis of iron fertilization experiments: from the Iron Age in the Age of Enlightenment. J Geophys Res 110; doi:10.1029/2004JC002601.

Dietz T, Dan A, and Shwom R. 2007. Support for climate change policy: social psychological and social structural influences. Rural Sociol 72: 185-214.

Fleming J. 2010. Fixing the sky: the checkered history of weather and climate control. New York, NY: Columbia University Press.

Fountain H. 2012. A rogue climate experiment outrages scientists. New York Times. Oct 18.

GAO (US Government Accountability Office). 2011. Climate engineering: technical status, future directions, and potential responses. Washington, DC: GAO. Report GAO-11-71.

Gardiner SM. 2011. Some early ethics of geoengineering the climate: a commentary on the values of the Royal Society report. Environ Value 20: 163-88.

Glaser B, Haumaier L, Guggenberger G, and Zech W. 2001. The "terra preta" phenomenon: a model for sustainable agriculture in the humid tropics. Naturwissenschaften 88: 37-41.

Gurwick N, Moore L, Kelly C, and Elias P. 2013. A systematic 
review of biochar research, with a focus on its stability in situ and its promise as a climate mitigation strategy. PLoS ONE 8: e75932.

Hansen J, Sato M, Kharecha P, et al. 2007. Climate change and trace gases. Philos T R Soc A 365: 1925-54.

Harrison K. 2012. A tale of two taxes: the fate of environmental tax reform in Canada. Rev Pol Res 29: 383-407.

Hartzell-Nichols L. 2012. Precaution and solar radiation management. Ethic Pol Environ 15: 158-71.

Herzog HJ. 2011. Scaling up carbon dioxide capture and storage: from megatons to gigatons. Energ Econ 33: 597-604.

House KZ, Baclig AC, Ranjan M, et al. 2011. Economic and energetic analysis of capturing $\mathrm{CO}_{2}$ from ambient air. P Natl Acad Sci USA 108: 20428-33.

Huijts NMA, Molin E, and Steg L. 2012. Psychological factors influencing sustainable energy technology acceptance: a review-based comprehensive framework. Renew Sust Energ Rev 16: $525-31$.

IEA (International Energy Agency). 2011. World energy outlook 2011. Paris, France: IEA.

IEA GHG (International Energy Agency Greenhouse Gas R\&D Programme). 2008. Carbon dioxide capture and storage in the clean development mechanism: assessing market effects of inclusion. Cheltenham, UK: IEA. Report Number 2008/13.

IPCC (Intergovernmental Panel on Climate Change). 2007. Climate change 2007: the Fourth Assessment Report of the Intergovernmental Panel on Climate Change. Cambridge, UK; New York, NY: Cambridge University Press.

IPCC (Intergovernmental Panel on Climate Change). 2013. Climate change 2013: the Fifth Assessment Report of the Intergovernmental Panel on Climate Change. Cambridge, UK; New York, NY: Cambridge University Press.

Jamieson D. 1996. Ethics and intentional climate change. Climatic Change 33: 323-36.

Kamishiro N and Sato T. 2009. Public acceptance of the oceanic carbon sequestration. Mar Pol 33: 466-71.

Keith DW. 2000. Geoengineering the climate: history and prospect. Annu Rev Energ Env 25: 245-84.

Kintisch E. 2010. Asilomar 2 takes small steps toward rules for geoengineering. Science 328: 22-23.

Kling G, Clark M, Wagner G, et al. 1987. The 1986 Lake Nyos gas disaster in Cameroon, West Africa. Science 236: 169-75.

Lal R. 2001. World cropland soils as a source or sink for atmospheric carbon. In: Sparks DL (Ed). Advances in agronomy, vol 71. San Diego, CA: Elsevier.

Landry M, Constantinou J, Latasa M, et al. 2000. Biological response to iron fertilization in the eastern equatorial Pacific (IronEx II). III. Dynamics of phytoplankton growth and microzooplankton grazing. Mar Ecol-Prog Ser 201: 57-72.

Lehmann J, Guant G, and Rondon M. 2006. Bio-char sequestration in terrestrial ecosystems - a review. Mitig Adapt Strat Gl 11: 403-27.

Mackey B, Prentice IC, Steffen W, et al. 2013. Untangling the confusion around land carbon science and climate change mitigation policy. Nat Clim Change 3: 552-57.

Malone EL, Dooley JJ, and Bradbury JA. 2010. Moving from misinformation derived from public attitude surveys on carbon dioxide capture and storage towards realistic stakeholder involvement. Int J Greenh Gas Con 4: 419-25.

Mercer A, Keith DW, and Sharp JD. 2011. Public understanding of solar radiation management. Environ Res Lett 6: 044006.

Morris J, Paltsev S, and Reilly J. 2012. Marginal abatement costs and marginal welfare costs for greenhouse gas emissions reductions: results from the EPPA model. Environ Model Assess 17: 325-36.

NERC (Natural Environment Research Council). 2010. Experiment Earth? Report on a public dialogue on geoengineering. Swindon, UK: NERC.
Pacala S and Socolow R. 2004. Stabilization wedges: solving the climate problem for the next 50 years with current technologies. Science 305: 968-72.

Preston CJ (Ed). 2012. Engineering the climate: the ethics of solar radiation management. Lanham, MD: Lexington Books.

Rickels W, Rehdanz K, and Oschlies A. 2012. Economic prospects of ocean iron fertilization in an international carbon market. Resour Energ Econ 34: 129-50.

Schmidt MWI, Torn MS, Abiven S, et al. 2011. Persistence of soil organic matter as an ecosystem property. Nature 478: 49-56.

Schneider SH. 1996. Geoengineering: could - or should - we do it? Climatic Change 33: 291-302.

Shaffer G. 2010. Long-term effectiveness and consequences of carbon dioxide sequestration. Nat Geosci 3: 464.

Sharp JD, Jaccard MK, and Keith DW. 2009. Anticipating public attitudes toward underground $\mathrm{CO}_{2}$ storage. Int J Greenh Gas Con 3: 641-51.

Shepherd J, Caldeira K, Cox P, et al. 2009. Geoengineering the climate: science, governance and uncertainty. London, UK: The Royal Society.

Silver M, Bargub S, Coalea S, et al. 2010. Toxic diatoms and domoic acid in natural and iron enriched waters of the oceanic Pacific. P Natl Acad Sci USA 107: 20762-67.

Sohi S, Lopez-Capel E, Krull E, and Bol R. 2009. Biochar, climate change and soil: a review to guide future research. Canberra, Australia: CSIRO. Land and Water Science Report 05/09.

Stephens JC, Bielicki J, and Rand GM. 2009. Learning about carbon capture and storage: changing stakeholder perceptions with expert information. Energy Procedia 1: 4655-63.

Stern N. 2007. The economics of climate change: the Stern review. Cambridge, UK: Cambridge University Press.

Tarr JA. 1996. The search for the ultimate sink: urban pollution in historical perspective. Akron, OH: University of Akron Press.

Terwel BW, Harinck F, Ellemers N, and Daamen DDL. 2010. Voice in political decision-making: the effect of group voice on perceived trustworthiness of decision makers and subsequent acceptance of decisions. J Exp Psychol-Appl 16: 173-86.

Tollefson J. 2008. UN decision puts brakes on ocean fertilization. Nat News 453: 704.

Tuana N, Sriver R, Svoboda T, et al. 2010. Towards integrated ethical and scientific analysis of geoengineering: a research agenda. Ethic Pol Environ 15: 136-57.

Vaughan $\mathrm{N}$ and Lenton T. 2011. A review of climate geoengineering proposals. Climatic Change 109: 745-90.

Wilson C, Grubler A, Gallagher KS, and Nemet GF. 2012. Marginalization of end-use technologies in energy innovation for climate protection. Nat Clim Change 2: 780-88.

Wingenter $\mathrm{O}$, Haase $\mathrm{K}$, Strutton $\mathrm{S}$, et al. 2004. Changing concentrations of $\mathrm{CO}, \mathrm{CH}_{4}, \mathrm{C}_{5} \mathrm{H}_{8}, \mathrm{CH}_{3} \mathrm{Br}, \mathrm{CH}_{3} \mathrm{I}$, and dimethyl sulfide during the Southern Ocean Iron Enrichment Experiments. P Natl Acad Sci USA 101: 8537-41.

Young OR, King LA, and Schroeder H. 2008. Institutions and environmental change: principal findings, applications, and research frontiers. Cambridge, MA: MIT Press.

Zoback MD and Gorelick SM. 2012. Earthquake triggering and large-scale geologic storage of carbon dioxide. P Natl Acad Sci USA 109: 10164-68.

${ }^{4}$ Department of Philosophy, Program on Values in Society and Program on Environment, University of Washington, Seattle, WA; ${ }^{5}$ Department of History, Ohio State University, Columbus, OH; ${ }^{6}$ Woods Hole Oceanographic Institution, Woods Hole, MA; ${ }^{7}$ Bay Paul Center for Comparative Molecular Biology and Evolution, Marine Biological Laboratory, Woods Hole, MA 